\title{
ABET 2000: What are the most important criteria to the supervisors of new engineering undergraduates?
}

\author{
Peter A. Koen, Pankaj Kohli \\ ASEE/ Stevens Institute of Technology and Rutgers - The State University of \\ New Jersey
}

\begin{abstract}
Engineering curricula in the next millennium will be guided by outcome assessments. ABET Engineering criteria 2000 establishes 11 proficiencies. Which attributes are more important? This study focuses on determining the critical attributes from supervisors of Stevens Institute of Technology engineering graduates in the last 3 years $(1994,1995$, and 1996) in order to better determine the industry skill set required of recent alumni. The most important attributes, in order of priority, were problem solving, ability to design and conduct experiments, recognition of the need to engage in life-long learning, understanding of professional and ethical responsibility and an ability to function on multi-disciplinary teams. Of less importance were depth and breath of engineering science indicating that the new curriculums will need to emphasize the "softer skills." Recent graduates attribute prioritization were nearly identical to their supervisors which further reinforces the relative importance of the attributes previously indicated.
\end{abstract}

\section{Introduction}

The new ABET criteria uses outcome assessment and indicates that graduates from engineering programs should demonstrate proficiencies in 11 critical areas ${ }^{1}$. While there is general agreement that these are the critical attributes necessary for engineering graduates there is no consensus as to which of the attributes are more important and should be stressed in an undergraduate program. The most important proficiencies need to be prioritized so that human and financial resources, new and revised curriculum may be structured to focus on the most important areas.

An assessment done at Arizona State University $^{2}$ found that the top five attributes, in terms of relative importance, by 17 industry representatives were problem solving, communication skills, ethics and professionalism, open mindiness and positive attitude, and math and science proficiency. Industry representatives were from companies that employ new engineering graduates. Their function within their company was not discussed.

A similar assessment done at Auburn University $^{3}$ found that the top five attributes, in terms of relative importance, by 298 industry representatives were the ability to learn on one's own, technical knowledge in a major engineering discipline, written communication skills, oral communication skills and experience with software to solve practical problems. Industry representatives were chosen from companies which place position announcements at Auburn or participate in the engineering cooperative education program. Thirty-six percent of the respondents were from human resource functions. 
The only similarities between the top five attributes between Arizonia State University ${ }^{2}$ and Auburn University ${ }^{3}$ were communication skills. This difference is probably due to the dissimilarities between the surveys. Questions addressed by Arizonia were significantly different than those contained in the Auburn study.

The survey discussed here was done at Stevens Institute of Technology in order to prioritize the key attributes within our industry segment. Industry representatives in our survey were restricted to supervisors of alumni who had graduated within the last 3 years. The skills expected of recent graduates would be different than those expected of seasoned professionals. We believed that the supervisors of recent alumni would be in the best position to assess the required needs of new graduates.

This paper reviews the process used to develop the survey and compares the results to previous surveys and the ABET criteria.

\section{Survey Instrument}

The survey instrument was developed by a faculty team consisting of 13 senior faculty representing each of the engineering and science departments at the Institute. The survey design utilized both the Arizonia State University ${ }^{2}$ survey and a previous pilot survey, done at the Institute, as starting points. A four step process, discussed in another ASEE Proceeding 5 , was utilized to obtain faculty consensus.

A total of 24 attributes were included in the survey and are shown in Table 1. These attributes are compared to the ABET Engineering criteria. The Institute survey covers 9 of the 10 survey questions included in the Arizonia State University ${ }^{2}$ study. "A motivation and capability to continue the learning experience" is included in the Arizonia State University ${ }^{2}$ study, but not contained in the Institute's survey. A similar comparison with the Auburn ${ }^{3}$ study shows similarities in 8 of the 16 attributes.

\section{Survey Implementation}

Two identical surveys were mailed to all 645 engineering undergraduates who graduated from the Institute during the last 3 years (i.e. 1994, 1995 and 1996). The alumni were requested to personally deliver the survey to their immediate supervisor. Confidentiality was maintained by separating each survey into 2 parts. The $1^{\text {st }}$ part, which was returned separately, identified the alumnus or their supervisor. The $2^{\text {nd }}$ part was the actual survey. This methodology allowed us to keep track of the respondents, but assured that the supervisor and alumni's responses were confidential and could not be linked.

The mailings were conducted in 3 rounds with extensive follow-up including phone calls and the use of reminder post cards in order to obtain the highest possible response rate. In addition 2 free domestic airline tickets were given away by lottery to one of the respondents in order to further increase the return percentages. 


\begin{tabular}{|c|c|}
\hline ABET 2000 Criteria & $\begin{array}{l}\text { Stevens Undergraduate Survey } \\
\end{array}$ \\
\hline $\begin{array}{l}\text { 1. Ability to apply knowledge } \\
\text { of mathematics, science and } \\
\text { engineering. }\end{array}$ & $\begin{array}{l}\text { 1. Fundamental understanding of mathematics. } \\
\text { 2. Fundamental understanding of Physical and Life Sciences. } \\
\text { 3. Breath of engineering sciences (Ability to understand the basic concepts in } \\
\text { most of the } 7 \text { engineering sciences: Mechanics of Solids; Fluid Mechanics; } \\
\text { Thermodynamics; Heat, Mass \& Momentum Transfer; Electrical Theory; Nature } \\
\text { \& Properties of Materials and Information Theory). }\end{array}$ \\
\hline $\begin{array}{l}\text { 2. Ability to design and } \\
\text { conduct experiments, as well } \\
\text { as to analyze and interpret } \\
\text { data. }\end{array}$ & $\begin{array}{l}\text { 4. Ability to use computers for communication, analysis and design. } \\
\text { 5. Effective decision making (prioritizing goals, generating alternatives and } \\
\text { choosing the best alternative). } \\
\text { 6. Effective problem solving. }\end{array}$ \\
\hline $\begin{array}{l}\text { 3. Ability to design a system, } \\
\text { component or process to meet } \\
\text { desired needs. }\end{array}$ & $\begin{array}{l}\text { 7. Effective project management skills. } \\
\text { 8. Depth of engineering sciences (Ability to understand the basic concepts in } \\
\text { most of the } 7 \text { engineering sciences). } \\
\text { Ability to use computers for communication, analysis and design (repeat as item } \\
\text { 4). }\end{array}$ \\
\hline $\begin{array}{l}\text { 4. Ability to function on multi- } \\
\text { disciplinary teams. }\end{array}$ & 9. Effective team skills. \\
\hline $\begin{array}{l}\text { 5. Ability to identify, formulate } \\
\text { and solve engineering } \\
\text { problems. }\end{array}$ & $\begin{array}{l}\text { 10. Ability to develop innovative approaches. } \\
\text { 11. Exert high levels of effort, strives to achieve goals } \\
\text { Effective problem solving. (repeat as item 6). }\end{array}$ \\
\hline $\begin{array}{l}\text { 6. An understanding of } \\
\text { professional and ethical } \\
\text { responsibility. }\end{array}$ & $\begin{array}{l}\text { 12. High professional and ethical standards. } \\
\text { 13. Mature, responsible and open minded with a positive attitude towards life. }\end{array}$ \\
\hline $\begin{array}{l}\text { 7. Ability to communicate } \\
\text { effectively }\end{array}$ & $\begin{array}{l}\text { 14. Effective listening skills. } \\
\text { 15. Effective oral communication. } \\
\text { 16. Effective writing skills. }\end{array}$ \\
\hline $\begin{array}{l}\text { 8. Broad education necessary } \\
\text { to understand the impact of } \\
\text { engineering solutions in a } \\
\text { global and societal context. }\end{array}$ & $\begin{array}{l}\text { 17. Appreciation and understanding of history, world affairs and cultures. } \\
\text { 18. Able to function in a multicultural and diverse work environment. } \\
\text { Breath of engineering sciences (repeat of item 3). }\end{array}$ \\
\hline $\begin{array}{l}\text { 9. Recognition of the need for } \\
\text { an ability to engage in life-long } \\
\text { learning. }\end{array}$ & 19. Motivation and capability to acquire and apply new technologies. \\
\hline $\begin{array}{l}\text { 10. Knowledge of } \\
\text { contemporary issues. }\end{array}$ & $\begin{array}{l}\text { Appreciation and understanding of history, world affairs and cultures (repeat of } \\
\text { item 17). }\end{array}$ \\
\hline $\begin{array}{l}\text { 11. Ability to use the } \\
\text { techniques, skills and modern } \\
\text { engineering tools necessary for } \\
\text { engineering practice }\end{array}$ & $\begin{array}{l}\text { 20. Fundamental understanding of cost estimation and accounting. } \\
\text { 21. Fundamental understanding of engineering economic analysis and decision } \\
\text { making. } \\
\text { 22. Knowledge of business strategies and management practices. } \\
\text { 23. Effective in dealing with real world complex and ambiguous problems. } \\
\text { 24. Able to transition from academic environment to the industrial environment. } \\
\text { Effective project management skills (repeat of item 7). } \\
\text { Able to function in a multicultural and diverse work environment(repeat of item } \\
\text { 18). }\end{array}$ \\
\hline
\end{tabular}

Table 1. Attributes of the Institute's undergraduate survey compared to the ABET 2000 Engineering Criteria. 
Each of the alumni and supervisors were asked to evaluate the importance of the skill to their company on a 5 point scale. Choosing a 5 would indicate that the skill is "extremely important" and a 1 if it is "not important." The alumni were also asked to rate how well the Institute prepared them, as well as how prepared they thought employees from other schools, in their company, were. The supervisors, in a similar manner were asked to rate how well the Institute prepared their employees, as well as how prepared employees graduating from other schools were. The importance of the skills to both the supervisors and alumni are discussed in this paper. Institute preparedness will be discussed in a later article.

\section{Survey Results}

The results from 124 alumni (20\% response rate) and 57 supervisors (9.3\% response rate) are shown in Table 2 . The attributes are shown in order of priority determined from the "top-box rating" or the percentage of supervisors and alumni who rated the attribute importance level as being "extremely important" to their company. The top five were effective problem solving; use of computers for communication, analysis and design; ability to develop innovative approaches; ability to exert high levels of effort, strives to achieve goals; and high professional and ethical standards.

Also shown in the same Table are the mean ratings by both the supervisors and alumni. The statistical significance between the supervisors and alumni are also shown. The rating of only 4 attributes, items 3,17, 22 and 23 were found to be significantly different with $p$ values less than 0.05. The ability to develop innovative approaches, item 3 , was the only item where the supervisors importance level was significantly $(\mathrm{p}=0.003)$ greater than that of the alumni.

These results are also shown in Table 3 by "top-box rating," but in terms of the ABET Criteria" Table 3 was determined by averaging the \% "top box rating" indicated in Table 2 according to the categories designated in column 2 of Table 1. The groupings in Table 3 provide similar results indicating that problem solving, ability to design and conduct experiments, recognition of the need to engage in life-long learning, act in a professional and ethical manner and the ability to function on multi-function teams are key attributes required of graduating engineers.

\section{Discussion}

This study seeks to assign relative priorities to the ABET criteria ${ }^{1}$ and indicates that the five most important criteria are effective problem solving, ability to design and conduct experiments, recognition of the need to engage in life-long learning, act in a professional and ethical manner and the ability to function on multi-function teams. Less important are the breath (item 19 of Table 2) and depth (item 24 of Table 2) of engineering science. These are important findings which should guide the direction of new curriculums which need to emphasize "softer skills." The challenge is to maintain the engineering skill level while supplementing it with "softer skills." These results help lead us into the new millennium where graduating engineers will need to have both superior technical skills and broad soft skills. Engineering schools have consistently provided graduates with technical skills, but provided little, if any, training into the "softer 
skills." Surveys like this one emphasize the importance of the softer skills which are needed to guide change.

\begin{tabular}{|c|c|c|c|c|c|}
\hline \multirow[b]{2}{*}{ Attribute } & \multicolumn{2}{|c|}{ Top Box Rating } & \multicolumn{3}{|c|}{ Mean Response } \\
\hline & $\begin{array}{l}\text { Supervisors } \\
(\%)\end{array}$ & $\begin{array}{c}\text { Alumni } \\
(\%)\end{array}$ & $\begin{array}{c}\text { Supervisor } \\
\text { s } \\
\text { (mean) }\end{array}$ & $\begin{array}{l}\text { Alumni } \\
\text { (mean) }\end{array}$ & $\begin{array}{c}\text { Significance } \\
\text { (p value) }\end{array}$ \\
\hline 1. Effective problem solving. & 73 & 75 & 4.70 & 4.67 & N.S. \\
\hline $\begin{array}{l}\text { 2. Use of computers for communication, analysis and } \\
\text { design. }\end{array}$ & 73 & 70 & 4.62 & 4.53 & N.S. \\
\hline 3. Ability to develop innovative approaches. & 72 & 54 & 4.68 & 4.39 & 0.003 \\
\hline 4. Exert high levels of effort, strives to achieve goals & 72 & 64 & 4.68 & 4.54 & N.S. \\
\hline 5. High professional and ethical standards. & 70 & 60 & 4.61 & 4.44 & N.S. \\
\hline $\begin{array}{l}\text { 6. Motivation and capability to acquire and apply new } \\
\text { technologies. }\end{array}$ & 63 & 63 & 4.49 & 4.48 & N.S. \\
\hline 7. Effective listening skills. & 58 & 63 & 4.55 & 4.54 & N.S. \\
\hline 8. Effective team skills. & 57 & 62 & 4.48 & 4.47 & N.S. \\
\hline 9. Effective decision making. & 54 & 68 & 4.49 & 4.53 & N.S. \\
\hline $\begin{array}{l}\text { 10. Ability to transition from the academic } \\
\text { environment to the industrial environment. }\end{array}$ & 52 & 50 & 4.30 & 4.28 & N.S. \\
\hline 11. Effective oral communication & 48 & 65 & 4.57 & 4.45 & N.S. \\
\hline $\begin{array}{l}\text { 12. Effective in dealing with real world complex and } \\
\text { ambiguous problems. }\end{array}$ & 46 & 53 & 4.31 & 4.35 & N.S. \\
\hline $\begin{array}{l}\text { 13. Mature, responsible and open minded with a } \\
\text { positive attitude towards life. }\end{array}$ & 45 & 50 & 4.3 & 4.31 & N.S. \\
\hline $\begin{array}{l}\text { 14. Ability to function in a multicultural and diverse } \\
\text { work environment. }\end{array}$ & 42 & 47 & 4.08 & 4.06 & N.S. \\
\hline 15. Effective writing skills. & 40 & 49 & 4.15 & 4.29 & N.S. \\
\hline 16. Fundamental understanding of mathematics. & 36 & 32 & 3.95 & 3.90 & N.S. \\
\hline 17. Effective project management skills. & 30 & 50 & 3.95 & 4.28 & 0.024 \\
\hline $\begin{array}{l}\text { 18. Fundamental understanding of physical and life } \\
\text { sciences. }\end{array}$ & 18 & 18 & 3.15 & 3.03 & N.S. \\
\hline 19. Breath of engineering science. & 17 & 26 & 3.23 & 3.34 & N.S. \\
\hline $\begin{array}{l}\text { 20. Fundamental understanding of engineering } \\
\text { economic analysis and decision making. }\end{array}$ & 15 & 24 & 3.30 & 3.57 & N.S. \\
\hline $\begin{array}{l}\text { 21. Appreciation and understanding of history, world } \\
\text { affairs and cultures. }\end{array}$ & 12 & 27 & 2.75 & 2.48 & N.S. \\
\hline $\begin{array}{l}\text { 22. Knowledge of business strategies and management } \\
\text { practices. }\end{array}$ & 10 & 35 & 3.20 & 3.81 & 0.001 \\
\hline 23. Understanding of cost estimation and accounting. & 8 & 8 & 3.37 & 3.71 & 0.042 \\
\hline 24. Depth of engineering sciences. & 7 & 14 & 2.98 & 2.98 & N.S. \\
\hline
\end{tabular}

Table 2. Survey results in order of priority. The "top box rating" is the percentage of supervisors or alumni who rated the attribute as being "extremely important." The mean responses are also shown. Significance between the supervisors and alumni is evaluated based on a two tailed t-test with the actual value shown for $p<0.10$.

The results of this survey are compared to that done by Arizonia State University ${ }^{2}$ in Table 4. The results are ordered in terms of mean values obtained in the Stevens' survey and are similar $(\mathrm{r}=0.54, \mathrm{p}=0.133)$ in terms of priority, except for items 2 and 7 . The differences cannot be attributed to wording since the questions in both surveys, for these items, were identical. The use of computers for communication, analysis and design was rated high in importance by Stevens 
and of much lower priority by Arizonia State University ${ }^{2}$. This low priority may be attributed to timing

\begin{tabular}{|c|c|c|}
\hline ABET 2000 Criteria & $\begin{array}{l}\text { Supervisors } \\
(\%)\end{array}$ & $\begin{array}{c}\text { Alumni } \\
(\%)\end{array}$ \\
\hline 1. Ability to identify, formulate and solve engineering problems. & 72 & 64 \\
\hline $\begin{array}{l}\text { 2. Ability to design and conduct experiments, as well as to analyze and interpret } \\
\text { data. }\end{array}$ & 67 & 71 \\
\hline 3. Recognition of the need for an ability to engage in life-long learning. & 63 & 63 \\
\hline 4. An understanding of professional and ethical responsibility. & 58 & 55 \\
\hline 5. Ability to function on multi-disciplinary teams. & 57 & 62 \\
\hline 6. Ability to communicate effectively & 49 & 59 \\
\hline 7. Ability to design a system, component or process to meet desired needs. & 37 & 45 \\
\hline $\begin{array}{l}\text { 8. Ability to use the techniques, skills and modern engineering tools necessary } \\
\text { for engineering practice }\end{array}$ & 25 & 41 \\
\hline 9. Ability to apply knowledge of mathematics, science and engineering. & 24 & 25 \\
\hline $\begin{array}{l}\text { 10. Broad education necessary to understand the impact of engineering solutions } \\
\text { in a global and societal context. }\end{array}$ & 24 & 33 \\
\hline 11. Knowledge of contemporary issues. & 12 & 27 \\
\hline
\end{tabular}

Table 3. Survey results, in order of priority, and structured in terms of the ABET 2000 criteria. The $2^{\text {nd }}$ and $3^{\text {rd }}$ columns are the percentage of alumni and supervisors who rated the attribute as "extremely important."

since the Arizonia State University ${ }^{2}$ study was done in the 1989-1990 academic year, when computers, the internet and the world wide web were not as ubiquitous as now. The difference between Stevens and Arizonia State University ${ }^{2}$ in the knowledge of business strategies and management practices is not as easily explained. The industry segment that is attracted to Stevens may require students with more business and management acumen. Alternatively, the relative importance of this attribute may have also changed with time. Indicating the need to repeat industry surveys at regular intervals. Unfortunately, a similar comparison could not be done with the Auburn University ${ }^{3}$ study due to the wide differences between the survey questions.

The relative rankings of attribute priority importance between industry representatives and alumni at both Arizonia State University ${ }^{2}$ study $(r=0.85, \mathrm{p}=0.002)$ and Auburn University ${ }^{3}$ $(\mathrm{r}=0.96, \mathrm{p}<0.001)$ are almost identical. While the attributes are different between the schools, due to the dissimilarities between the questions, the priorities between alumni and industry are nearly the same. These similarities might be expected since the alumni are probably a cohort of industry representatives, since neither survey restricted the alumni to those who had recently graduated. In contrast, distinct and separate industry cohorts consisting of alumni who graduated within the last 3 years and their supervisors, were sampled in this study. The similarities between the alumni and their supervisors follow a similar pattern in this study $(\mathrm{r}=0.72, \mathrm{p}<0.001)$ with no significant differences in their respective scoring in 20 of the 24 attributes (Table 2). In addition, the priority ranking in Table 2 is almost identical for both groups. These results indicate that recently employed students become quickly assimilated into the work force and rapidly understand the needs of their employers. Perhaps industry surveys, similar to this, no longer have to make 
distinctions between alumni and industry representatives since they may all be part of the same cohort.

\begin{tabular}{|l|c|c|}
\hline \multicolumn{1}{|c|}{ Attribute } & $\begin{array}{c}\text { Stevens' } \\
\text { Supervisors } \\
\text { (mean) }\end{array}$ & $\begin{array}{c}\text { U of } \mathbf{A}^{5} \\
\text { Industry } \\
\text { Representatives } \\
\text { (mean) }\end{array}$ \\
\hline 1. Effective problem solving. & 4.70 & 4.64 \\
\hline 2. Use of computers for communication, analysis and design. & 4.62 & 2.69 \\
\hline 3. High professional and ethical standards. & 4.44 & 4.15 \\
\hline $\begin{array}{l}\text { 4. Mature, responsible and open minded with a positive attitude } \\
\text { towards life. }\end{array}$ & 4.30 & 4.15 \\
\hline $\begin{array}{l}\text { 5. Effective oral and written communication. (Items 11 and 15 } \\
\text { from Table 2 were averaged.) }\end{array}$ & 4.36 & 4.23 \\
\hline $\begin{array}{l}\text { 6. Fundamental understanding of mathematics and science. (Items } \\
\text { 16 and 18 from Table 2 were averaged.) }\end{array}$ & 3.55 & 4.00 \\
\hline 7. Knowledge of business strategies and management practices. & 3.20 & 2.85 \\
\hline $\begin{array}{l}\text { 8. Breath and depth of engineering science. (Items 19 and 24 } \\
\text { from Table 2 were averaged.) }\end{array}$ & 3.11 & 3.69 \\
\hline $\begin{array}{l}\text { 9. Appreciation and understanding of history, world affairs and } \\
\text { cultures. }\end{array}$ & 2.75 & 2.64 \\
\hline
\end{tabular}

Table 4. Stevens survey results compared to that done by Arizonia State University ${ }^{2}$. Stevens results were averaged in items 5, 6 and 8 so they may be directly compared to the Arizonia study.

Identical prioritization was not seen when undergraduate students views of the attributes are compared with the industry at either Arizonia State University ${ }^{2}(r=0.54, p=0.111)$ or Auburn University $^{3}$. (Data was unavailable in the Auburn University ${ }^{3}$ study to do similar correlations.) At Arizonia State University ${ }^{2}$ senior undergraduates ranked ethics and professionalism 9 of 10 while both industry and alumni ranked this attribute as 3 out of 10. At Auburn University students rated written and oral communication as $14^{\text {th }}$ and $15^{\text {th }}$ of 16 attributes, while industry representatives rated them as $3^{\text {rd }}$ and $4^{\text {th }}$ in terms of importance. These results indicate that undergraduates have a poor understanding of the needs of industry. The nearly identical comparison of recent graduates with industry attributes, reported in this study, suggest that the graduating students quickly learn the needs of their employers.

This study, along with others, prioritizes industry attributes. Problem solving, ability to design and conduct experiments, recognition of the need to engage in life-long learning, act in a professional and ethical manner and the ability to function on multi-function teams should be key goals for modifying courses and curriculum. The similarities between the alumni and the industry representatives, and between this study and Arizonia State University ${ }^{2}$ indicates that the important attributes are well known and well prioritized by industry. The key challenge for engineering schools is to adopt and embrace these new priorities. 


\section{Bibliography}

1. Engineering Criteria 2000, December 1997, $3^{\text {rd }}$ edition, Accreditation Board for Engineering and Technology, Maryland.

2. Evans, D.L., Beakley, G.C., Crouch, P.E., and Yamaguchi, G.T., “Attributes of Engineering Graduates and Their Impact on Curriculum Design,” Journal of Engineering Education, pg. 203-211, October 1993.

3. Benefield, L.D., Trentham, L.L., Khodadadi, K., and Walker, W.F., "Quality Improvement in a College Engineering Instructional Program,” Journal of Engineering Education, pg. 57-68, January 1997.

4. Koen, P.A., "Undergraduate Engineering Skill Preparedness,” Proceedings, 1996 ASEE Annual Conference, CD ROM Reference \#2242.

5. Koen, P.A., "Using an industry survey to obtain faculty support for ABET 200 criteria," Proceedings, 1998 ASEE Annual Conference, CD ROM Reference \#2642.

\section{Biographical Information}

Dr. PETER A. KOEN is a full time Associate Professor in the Wesley J. Howe School of Technology Management at Stevens Institute of Technology in Hoboken, New Jersey. Dr. Koen's background includes over 19 years of experience in companies such as Becton Dickinson and AT\&T Bell Laboratories. Dr. Koen is supporting the Institute by doing this survey in order to better align curriculum initiatives with the needs of the employers.

PANKAJ KOHLI is a doctoral candidate in Marketing in the Ph.D. Program at Rutgers, The State University of New Jersey. His research interests include marketing channels, marketing-technology and marketing strategy interfaces, and structural equations modeling applications. 